\title{
As correntes da Geografia e da Educação Ambiental presentes na BNCC e nas DCNEA
}

\section{The currents of Geography and Environmental Education present in the BNCC and the DCNEA}

\author{
Las corrientes de Geografía y Educación Ambiental presentes en BNCC y \\ DCNEA
}

\section{Resumo}

A Geografia e a Educação Ambiental-EA são campos do conhecimento que, através de seus referenciais, possibilitam aos seres humanos diversas formas de interpretação e de interação com o espaço. Assim, esta pesquisa tem o objetivo de investigar quais correntes do pensamento geográfico e da EA estão presentes na Base Nacional Comum Curricular-BNCC e nas Diretrizes Curriculares Nacionais para a Educação Ambiental-DCNEA. Para isso, foi realizado um estudo qualitativo do tipo crítico analítico nos referidos documentos, com auxílio do software de análise de dados qualitativos ATLAS.ti, a partir dos ciclos de codificação do Saldaña (2013). Os principais resultados apontam que, na BNCC, se apresentam enfaticamente as correntes crítica, humanista e socioambiental da Geografia e as correntes denominadas de moral/ética, naturalista, crítica, conservacionista e de sustentabilidade da EA. Nas DCNEA aparecem as correntes regional, humanista, socioambiental e a crítica da Geografia e as correntes moral/ética, crítica, sistêmica, humanista, científica, de ecoeducação, sustentabilidade e práxica.

Palavras Chaves: Base Nacional Comum Curricular. Diretrizes Curriculares Nacionais para a Educação Ambiental. Educação Ambiental. Geografia.

\begin{abstract}
Geography and Environmental Education-EA are fields of knowledge that, through their references, enable human beings to have different forms of interpretation and interaction with space. Thus, this research aims to investigate which currents of geographical thought and EA are present in the National Common Curricular Base-BNCC and in the National Curriculum Guidelines for Environmental Education-DCNEA. A qualitative critical analytical study was carried out on these documents, with the aid of the qualitative data analysis software ATLAS.ti, based on the coding cycles of Saldaña (2013). The main results point out that BNCC emphatically presents the critical, humanistic and socioenvironmental currents of Geography and the currents called moral/ethics, naturalistic, critical, conservationist and EA sustainability. In the DCNEA the regional, humanist, socio-environmental currents and the criticism of Geography and the currents moral/ethics, criticism, systemic,
\end{abstract}


humanistic, scientific, ecoeducation, sustainability and praxic currents appear.

Keywords: Common National Curriculum Base. National Curricular Guidelines for Environmental Education. Environmental education. Geography.

\section{Resumen}

La Geografía y la Educación Ambiental-EA son campos de conocimiento que, a través de sus referencias, permiten al ser humano tener diferentes formas de interpretación e interacción con el espacio. Así, esta investigación tiene como objetivo investigar qué corrientes de pensamiento geográfico y EA están presentes en la Base Curricular Común Nacional-BNCC y en las Directrices Curriculares Nacionales de Educación Ambiental-DCNEA. Sobre estos documentos se realizó un estudio analítico crítico cualitativo, con la ayuda del software de análisis de datos cualitativos ATLAS.ti, basado en los ciclos de codificación de Saldaña (2013). Los principales resultados señalan que BNCC presenta enfáticamente las corrientes críticas, humanísticas y socioambientales de la Geografía y las corrientes denominadas moral/ética, naturalista, crítica, conservacionista y EA de sostenibilidad. En la DCNEA aparecen las corrientes regionales, humanistas, socioambientales y la crítica de la Geografía y las corrientes moral/ética, crítica, sistémica, humanista, científica, ecoeducación, sustentabilidad y praxis..

Palabras Clave: Base de currículo nacional común. Lineamientos Curriculares Nacionales para la Educación Ambiental. Educación ambiental. Geografía

\section{Introdução}

A Geografia e a EA são campos do conhecimento constitutivos do processo de formação da pessoa humana. No âmbito da educação formal, esses campos buscam formar o indivíduo em vista da sua atuação no mundo e da compreensão de mundo. A geografia ao longo da sua história passou por diversas transformações e, paulatinamente, foi se caracterizando a partir das particularidades do tempo, do espaço e do modo de compreender o papel do ser humano no espaço. De igual maneira, a EA foi se desenvolvendo no devir histórico e trazendo as marcas do tempo, do espaço e da compreensão do ser humano em relação ao meio ambiente e aos seus pares.

A partir desses processos de formação e de consolidação dos modos de percepção do mundo, ambos os campos do saber formaram modos interpretativos de se desenvolver e de amparar os seus trabalhos. No campo da geografia, a história do pensamento desta ciência nos aponta correntes deste campo que trazem consigo modos diferentes de fazer ciência, de ensinar a Geografia e de conduzir o modo de compreensão das relações que ocorrem no tempo e no espaço.

Para a realização desta pesquisa utilizou-se as correntes do pensamento geográfico, pois estas correspondem ao modo como a Geografia foi sendo sistematizada ao longo da história do pensamento geográfico. Dentre as várias correntes, elegeu-se a esquematização proposta por Claval (2009), Mendonça (2009) e Moraes (2007), contemplando sete correntes, a saber: o Determinismo, o Possibilismo e o Método Regional, amparados na matriz epistemológica positivista (essas correntes são denominadas de Tradicionais ou Clássicas), a Geografia quantitativa de raiz epistemológica neopositivista denominada de Moderna, a Geografia Crítica, amparada no materialismo histórico-dialético, a Geografia Humanista, de raiz fenomenológica e, por fim, a Geografia Socioambiental, de raiz sistêmica. As três últimas são consideradas Geografias contemporâneas. 
No campo da EA, optou-se pela utilização da cartografia da EA proposta por Sauvé (2005). Essa esquematização apresenta 15 correntes nas quais se amparam os modos de desenvolvimento da EA e de compreensão do meio ambiente e das relações que o ser humano desenvolve no espaço. As correntes apresentadas são: a naturalista, a conservacionista, a resolutiva, a sistêmica, a cientifica, a humanista, a moral/ética, a holística, a biorregionalista, a práxica, a crítica, a feminista, a etnográfica, a ecoeducação e, por fim, a de sustentabilidade.

A cartografia da EA apresentada pela autora serve como guia para as práticas da EA nos mais diversos ambientes formativos. Reconhecendo que, tanto as correntes da Geografia, quanto as da EA, carregam características do modo de desenvolvimento da educação em ambos os campos do saber, traz-se para este trabalho a seguinte questão: Quais correntes da Geografia e da EA estão presentes na BNCC e nas DCNEA?

A opção por estes dois documentos leva em consideração que são bases e diretrizes de orientação para a educação básica no Brasil.

Para responder à questão norteadora desta pesquisa, foram utilizados referencias teóricos do campo da Geografia e da EA. O percurso metodológico, por sua vez, pautou-se em um estudo de cunho qualitativo, analítico crítico, a partir dos ciclos de codificação propostos por Saldaña (2013). Para tanto, os documentos da BNCC e das DCNEA foram exportados para o software de análise de dados qualitativos ATLAS.ti e analisados à luz do referencial teórico apresentado.

Os principais resultados apontam que, na BNCC, se apresentam enfaticamente as correntes crítica, humanista e socioambiental da Geografia e as correntes denominadas de moral/ética, naturalista, crítica, conservacionista e de sustentabilidade da EA. Em relação às DCNEA, aparecem as correntes regional, humanista, socioambiental e a crítica da Geografia e as correntes moral/ética, crítica, sistêmica, humanista, científica, de ecoeducação, sustentabilidade e práxica. A identificação destas correntes da Geografia e da EA possibilitam aos educadores a promoção do ensino da Geografia e da EA pautados em referenciais e práticas que dialoguem entre si e que favoreçam aprendizagens e vivências contínuas, em substituição das atividades pontuais e desarticuladas que podem ocorrer nos ambientes escolares.

\section{Materiais e métodos}

O Determinismo Ambiental surge na Alemanha no final do século XIX e possui como defensor, Friedrich Ratzel. "Foi o determinismo ambiental o primeiro paradigma a caracterizar a Geografia que emerge no final do século XIX, com a passagem do capitalismo concorrencial para uma fase monopolista e imperialista" (CORREA, 1986, p. 9).

Para os teóricos dessa linha geográfica, as mais diversas formas de organização espacial e as desigualdades encontradas na terra eram oriundas e explicáveis por meio das determinantes condições ambientais, de forma especial, as condições climáticas as quais os ambientes e os indivíduos estavam expostos.

Esta ideia levou os geógrafos ingleses e americanos, sobretudo, ao "[...] determinismo declarado, uma vez que para eles o homem era um produto do meio" (ANDRADE, 1987, p. 54). Em consequência disso, compreendia-se o desenvolvimento dos povos e nações a partir de sua localização geográfica.

Em contraposição à visão determinista de Ratzel, surge na França, a partir dos estudos de Paul Vidal de La Blache, o Possibilismo Geográfico. Para essa corrente, o ser humano é identificado como ser agente que atua sobre o meio e o transforma. Nessa perspectiva, Moraes (2007, p. 81) afirma que "essa corrente geográfica concebe o homem como um ser ativo, que sofre a influência do meio, porém que atua sobre esse, transformando-o".

A Geografia Regional, sistematizada na França a partir dos estudos de La Blache, enfatiza os conceitos de região e gênero de vida. Para o fundador dessa corrente, quando se trata de região, não é necessário procurar os limites, é necessário conceber a região como uma espécie de auréola que se estende sem limites bem determinados, que circunda e que 
avança.

Na Geografia Quantitativa a compreensão é de que os métodos científicos são comuns a todas as ciências, "[...] há métodos científicos para a pesquisa geográfica, mas não há métodos geográficos de pesquisa" (CHRISTOFOLETTI, 1985, p. 16). Amparado nessa visão, as pesquisas, de todas as ciências, em menor ou maior graus, seguiriam o mesmo modo de fazer ciência.

Dentro do escopo metodológico da Geografia Quantitativa teve predominância a "[...] observação empírica, a quantificação dos fatos, a criação e verificação de hipóteses, a proposição de predições baseadas nas teorias e leis científicas e, grande importância é dada ao critério da refutabilidade" (SOUZA et al., 2009, p. 5).

Na década de 1970, surge a chamada Geografia Crítica, em oposição à linearidade da Geografia Quantitativa e à acriticidade da Geografia Tradicional.

Essa corrente possui como principal característica a ressignificação dos conteúdos estudados na ciência geográfica e nas escolas. De acordo com Vesentini (1994, p. 36) a "corrente crítica trata de uma Geografia que concebe o espaço geográfico como espaço social, construído, pleno de lutas e conflitos sociais e coloca-se como ciência social". Essa concepção é a que será utilizada como basilar para a identificação da corrente crítica da Geografia.

A corrente geográfica denominada de Geografia Humanista se insere como contexto temporal da Geografia Crítica e, em menor ou maior grau, traz como marca para o seu surgimento o descontentamento dos geógrafos em relação à Geografia Quantitativa, em meados dos anos de 1960 no Estados Unidos.

Para Andrade (1987, p. 114) "Esta corrente tem grande campo de ação, participando de uma luta em defesa do meio ambiente". Essa concepção do modo de fazer ciência geográfica leva em consideração a natureza e a gama de experiências e pensamentos humanos "a qualidade e a intensidade de uma emoção, a ambivalência e a ambiguidade dos valores e atitudes, a natureza e o poder do símbolo e as características das intenções e das aspirações humanas" (TUAN, 1983, p. 10).

No contexto da ascensão do capitalismo, concomitante à Geografia Humanista, surge a Geografia Socioambiental. O enfoque epistemológico que dá sustentação a essa corrente consiste na base sistêmica de compreensão da realidade. Na visão de Limberger (2006, p. 97) "a abordagem sistêmica aparece como alternativa ou complemento ao pensamento cartesiano" enfatizando que não foi objetivo destituir o modo cartesiano, mas ampliá-lo em vista de uma maior compreensão da realidade.

Apresentadas as correntes do pensamento geográfico que embasam este trabalho, expõe-se também as correntes da EA propostas por (SAUVÉ, 2005). Segundo a pesquisadora, este mapeamento das diversas concepções da EA deve ser considerado como possibilidade de compreensão das práticas e das epistemologias sob as quais a EA se desenvolve, considerando que não são caixas nas quais se fecham as concepções. A partir do mapeamento proposto pela autora, concebe-se 15 correntes da EA.

A corrente naturalista possui como uma das principais características a preocupação com a natureza, segundo a qual, é percebida como morada do ser humano. No âmbito educacional, ela possui enfoque cognitivo, experiencial, afetivo, espiritual ou artístico. No campo do enfoque cognitivo, "pode se resumir à transmissão de conhecimentos sobre a natureza” (SAHEB, 2008, p. 07). Essa compreensão é utilizada como norteadora para identificação da corrente naturalista da EA.

A conservacionista/recursista centra suas discussões sobre a ideia de conservação do meio ambiente em prol da manutenção da vida humana. Em menor ou maior grau, essa corrente orientou a EA no Brasil. A "EA brasileira, em seus primórdios, foi orientada por uma visão hegemônica de perfil conservacionista, tecnicista, conservadora e apolítica, embora essa não fosse sua expressão exclusiva" (LIMA, 2009, p. 149).

A resolutiva, "surgida na década de 1970 [...] considera a crise ambiental como um conjunto de problemas e procura informar ou estimular as pessoas a [...] desenvolver habilidades voltadas para a resolução" (ALENCASTRO; SOUZA-LIMA, 2015, p. 31). Essa 
definição será tomada nesta pesquisa como base para a identificação da corrente.

Por sua vez,"a corrente sistêmica em EA se apoia, entre outras, nas contribuições da ecologia e tem como objetivo a superação da visão fragmentada de meio ambiente em prol da sistêmica" (SAHEB, 2013, p. 16). Ressalta-se que essa é a concepção da corrente sistêmica adotada por esta pesquisa.

A científica assemelha-se à sistêmica na questão do método que está baseado na observação e na experimentação. Partindo do método indutivo, objetivando a natureza como campo de estudo, essa corrente enfatiza procedimentos pautados no método, no rigor e na repetibilidade da investigação.

A humanista é apresentada como aquela que enfatiza a dimensão humana do meio ambiente. Por ela, busca-se compreender a relação que o ser humano estabelece com o meio em que vive. Aqui a natureza que, nas correntes anteriores era percebida com objeto de estudo, ganha o status de lugar de vivência, de realização e de relação humana.

A ética/moral sugere que os problemas ambientais decorrem da formação de uma ética antropocêntrica na qual o ser humano é percebido como senhor e detentor do direito de dominar o meio ambiente. Esta concepção antropocêntrica tem bases no processo de positivação da ciência e do ser humano. Ao colocar o ser humano no centro do mundo, coube a ele agir da maneira que lhe favorecesse.

A holística, aponta a fragmentação da pessoa humana e da realidade como um dos principais problemas para a EA. A proposta por ela apresentada, apregoa a necessidade de levar em consideração a realidade global; "o sentido de "global" se refere à totalidade de cada ser, de cada realidade, e à rede de relações que une os seres entre si, em conjuntos onde eles adquirem sentido" (SAHEB, 2013, p.16).

A biorregionalista considera que os aspectos regionais são destacados nela como fonte de identidade e relação. Na Geografia, o regionalismo marca uma corrente de pensamento e sustentação do método geográfico. O conceito utilizado como base para a biorregião tem fundamento geográfico na categoria de região.

A perspectiva de trabalho da corrente práxica está amparada na transformação da sociedade. Concebendo o ser humano como agente crítico do modelo vigente que busca promover a educação por meio da ação.

A crítica e a práxica possuem bases semelhantes, assim como a científica e a sistêmica. Ambas buscam a tomada de consciência em vista da resolução de problemas por meio social.

A feminista possui caráter contestatório do modo de organização social e das relações estabelecidas com a natureza. O seu foco principal de discussão está amplamente inserido nas causas de empoderamento feminino. Essa compreensão é a utilizada por esta pesquisa.

A concepção etnográfica enfatiza a relação estabelecida entre os seres humanos e o seu lugar de vivência, propondo um afastamento das concepções etnocêntricas, que em sua maioria, tomam como referência as categorias de pensamento de comunidade externas.

A ecoeducação, diferentemente da maioria das correntes apresentadas, não busca de imediato a resolução de problemas. Antes, se vale da relação estabelecida entre o ser humano e o meio ambiente, ressaltando o desenvolvimento pessoal do indivíduo, para fundamentar o modo responsável de atuação do ser humano no meio em que vive.

A corrente da sustentabilidade predominou largamente nos documentos que fazem parte do desenvolvimento da EA. Influenciada pela concepção de desenvolvimento sustentável, segundo a qual é preciso consumir de modo responsável visando garantir os recursos para as próximas gerações, essa corrente ganhou espaço nas escolas por meio de projetos de desenvolvimento sustentável.

Havendo apresentado o referencial teórico sob o qual esta pesquisa se embasa, trazse para a discussão os resultados encontrados.

\section{Resultados}

A partir do referencial teórico e do método empregado na exploração dos dados, o quadro 1 apresenta os dados coletados e sistematicamente organizados. Aponta-se que é 
possível a existência de outras interpretações desses documentos a depender do arcabouço teórico nos campos da Geografia e da EA sob o qual o pesquisador se ampare. Visto que "[...] a interpretação fala tanto do fenômeno interpretado quanto do mundo da vida e do universo cultural do sujeito que interpreta" (CARVALHO, 2012, p. 78). Destaca-se que os quadros 1 e 2 têm a intenção de demonstrar o quantitativo de citações vinculadas a cada corrente da Geografia e da EA nos diplomas normativos pesquisados, bem como, oferecer um exemplo do que o pesquisador teve como base para a essa vinculação.

Quadro 1 - Panorama das concepções geográficas presentes na BNCC e nas DCNEA

\begin{tabular}{|c|c|c|c|c|}
\hline \multirow{3}{*}{ 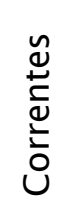 } & \multicolumn{4}{|c|}{ Documentos } \\
\hline & \multicolumn{2}{|r|}{ BNCC } & \multicolumn{2}{|r|}{ DCNEA } \\
\hline & Qt & Exemplo & Qt & Exemplo \\
\hline 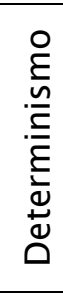 & 03 & $\begin{array}{l}\text { Descrever as rotas de dispersão da } \\
\text { população humana pelo planeta (...), } \\
\text { discutindo os fatores históricos e } \\
\text { condicionantes físico-naturais } \\
\text { associados à distribuição da } \\
\text { população humana pelos } \\
\text { continente. }\end{array}$ & 0 & \\
\hline 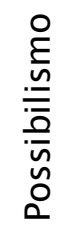 & 08 & $\begin{array}{l}\text { Analisar distintas interações das } \\
\text { sociedades com a natureza, com } \\
\text { base na distribuição } \\
\text { componentes físico-naturais. }\end{array}$ & 0 & \\
\hline $\begin{array}{l}\overline{0} \\
\frac{0}{0} \\
\frac{0}{\mathscr{Q}} \\
\propto\end{array}$ & 20 & $\begin{array}{l}\text { Entender a dimensão sociocultural e } \\
\text { geopolítica (...) por meio das } \\
\text { situações geográficas } r \\
\text { contextualizam os temas da } \\
\text { Geografia regional. }\end{array}$ & 06 & $\begin{array}{l}\text { Articulação na abordagem de uma } \\
\text { perspectiva crítica e transformadora dos } \\
\text { desafios ambientais a serem enfrentados } \\
\text { pelas atuais e futuras gerações, nas } \\
\text { dimensões locais, regionais, nacionais e } \\
\text { globais; }\end{array}$ \\
\hline 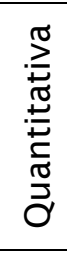 & 3 & 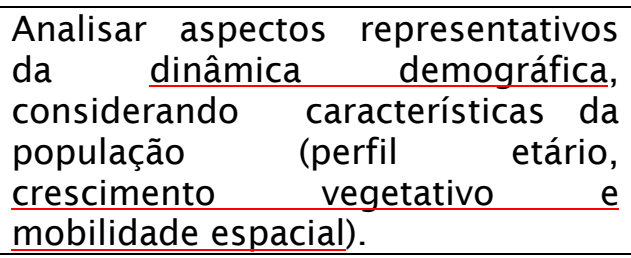 & 0 & \\
\hline 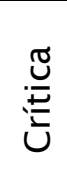 & 65 & $\begin{array}{l}\text { Exercitar a curiosidade intelectual e } \\
\text { recorrer à abordagem própria das } \\
\text { ciências, incluindo a investigação, a } \\
\text { reflexão, a análise crítica, }\end{array}$ & 17 & $\begin{array}{l}\text { Aprofundamento do pensamento crítico- } \\
\text { reflexivo mediante estudos científicos, } \\
\text { socioeconômicos, políticos e históricos }\end{array}$ \\
\hline 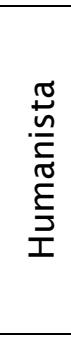 & 31 & $\begin{array}{l}\text { propõe-se a retomada da identidade } \\
\text { sociocultural, do reconhecimento } \\
\text { dos lugares de vivência e da } \\
\text { necessidade do estudo sobre os } \\
\text { diferentes e desiguais usos do } \\
\text { espaço, para uma tomada de } \\
\text { consciência sobre a escala da } \\
\text { interferência humana no planeta. }\end{array}$ & 20 & $\begin{array}{l}\text { projetos e atividades, inclusive artísticas e } \\
\text { lúdicas, que valorizem o sentido de } \\
\text { pertencimento dos seres humanos à } \\
\text { natureza, a diversidade dos seres vivos, as } \\
\text { diferentes culturas locais, a tradição oral, } \\
\text { entre outras. }\end{array}$ \\
\hline
\end{tabular}




\begin{tabular}{|c|c|c|c|c|}
\hline 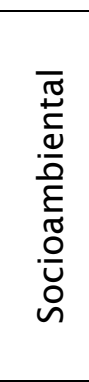 & 21 & $\begin{array}{l}\text { defender ideias, pontos de vista e } \\
\text { decisões comuns que respeitem e } \\
\text { promovam os direitos humanos, a } \\
\text { consciência socioambiental e o } \\
\text { consumo responsável em âmbito } \\
\text { local, regional e global, com } \\
\text { posicionamento ético em relação ao } \\
\text { cuidado de si mesmo, dos outros e } \\
\text { do planeta. }\end{array}$ & 15 & $\begin{array}{l}\text { A Educação Ambiental visa à construção de } \\
\text { conhecimentos, ao desenvolvimento de } \\
\text { habilidades, atitudes e valores sociais, ao } \\
\text { cuidado com a comunidade de vida, a } \\
\text { justiça e a equidade socioambiental, e a } \\
\text { proteção do meio ambiente natural e } \\
\text { construído. }\end{array}$ \\
\hline
\end{tabular}

Fonte: Autores (2020)

O panorama apresentado no Quadro 1 apresenta as citações extraídas da BNCC e das DCNEA vinculadas às correntes da Geografia e da EA. Ressalta-se que o quantitativo entre um documento e outro não serve de base para estabelecer um comparativo quantitativo em decorrência da discrepante extensão entre um documento e outro.

No que se refere às correntes da Geografia, percebe-se que o Determinismo, o Possibilismo e a corrente Quantitativa não apareceram nas DCNEA. Esse dado sinaliza a percepção de que esse diploma normativo tem se norteado por concepções mais recentes e amplas do modo de conceber a relação entre os seres humanos e os seus pares e com o meio do qual ele é parte constituinte.

Buscando oferecer um panorama dos mesmos diplomas normativos em relação às correntes da EA, o Quadro 2 traz citações desses diplomas vinculadas a essas correntes.

Quadro 2 - Panorama das concepções em EA presentes na BNCC e nas DCNEA

\begin{tabular}{|c|c|c|c|c|}
\hline \multirow{3}{*}{ 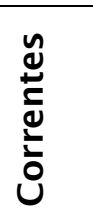 } & \multicolumn{4}{|c|}{ Documentos } \\
\hline & \multicolumn{2}{|r|}{ BNCC } & \multicolumn{2}{|r|}{ DCNEA } \\
\hline & Qt & Exemplo & $\overline{Q t}$ & Exemplo \\
\hline 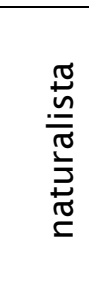 & 05 & $\begin{array}{l}\text { O ensino das Ciências Humanas } \\
\text { deve promover explorações } \\
\text { sociocognitivas, afetivas e lúdicas } \\
\text { capazes de potencializar sentidos e } \\
\text { experiências com saberes sobre a } \\
\text { pessoa, o mundo social e a } \\
\text { natureza. }\end{array}$ & 03 & $\begin{array}{l}\text { Observação e estudo da natureza e de seus } \\
\text { sistemas de funcionamento para } \\
\text { possibilitar a descoberta de como as } \\
\text { formas de vida relacionam-se entre si e os } \\
\text { ciclos naturais interligam-se e integram-se } \\
\text { uns aos outros; }\end{array}$ \\
\hline 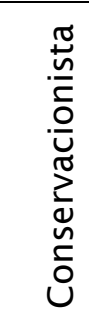 & 29 & $\begin{array}{l}\text { a compreensão das formas como } \\
\text { os seres humanos fazem uso dos } \\
\text { recursos da natureza ao longo da } \\
\text { história. }\end{array}$ & 19 & $\begin{array}{l}\text { avaliação e gestão de projetos de } \\
\text { intervenção e ações de sustentabilidade } \\
\text { socioambiental na instituição educacional e } \\
\text { na comunidade, com foco na prevenção de } \\
\text { riscos, na proteção e preservação do meio } \\
\text { ambiente e da saúde humana e na } \\
\text { construção de sociedades sustentáveis. }\end{array}$ \\
\hline 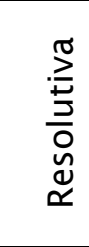 & 22 & 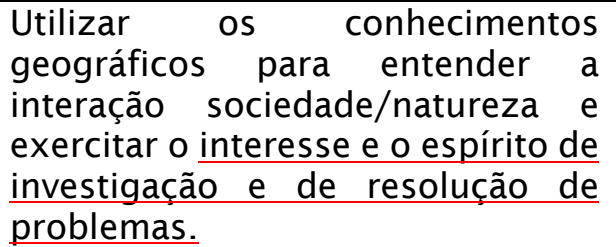 & 05 & $\begin{array}{l}\text { O estabelecimento das relações entre as } \\
\text { mudanças do clima e o atual modelo de } \\
\text { produção, consumo, organização social, } \\
\text { visando à prevenção de desastres } \\
\text { ambientais e à proteção das comunidades; }\end{array}$ \\
\hline
\end{tabular}




\begin{tabular}{|c|c|c|c|c|}
\hline 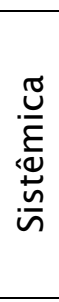 & 05 & 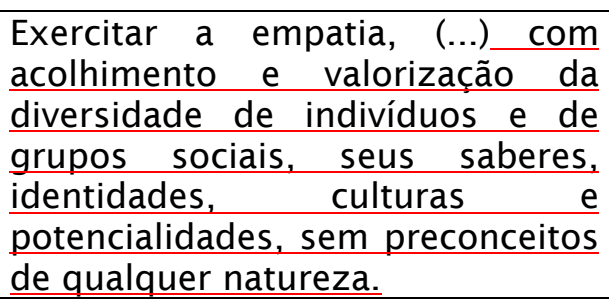 & 07 & $\begin{array}{l}\text { A EA deve adotar uma abordagem que } \\
\text { considere a interface entre a natureza, a } \\
\text { sociocultura, a produção, o trabalho, o } \\
\text { consumo. }\end{array}$ \\
\hline 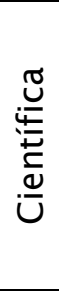 & 13 & $\begin{array}{l}\text { Exercitar a curiosidade intelectual e } \\
\text { recorrer à abordagem própria das } \\
\text { ciências, incluindo a investigação, } \\
\text { a reflexão, (...) para investigar } \\
\text { causas, elaborar e testar hipóteses, } \\
\text { formular e resolver problemas e } \\
\text { criar soluções }\end{array}$ & 13 & $\begin{array}{l}\text { A totalidade como categoria de análise } \\
\text { fundamental em formação, análises, } \\
\text { estudos e produção de conhecimento } \\
\text { sobre o meio ambiente; }\end{array}$ \\
\hline 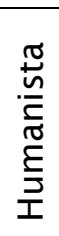 & 22 & $\begin{array}{l}\text { Orientado pelos princípios éticos, } \\
\text { políticos e estéticos que visam à } \\
\text { formação humana integral e à } \\
\text { construção de uma sociedade } \\
\text { justa, democrática e inclusiva, }\end{array}$ & 11 & $\begin{array}{l}\text { Interdependência entre o meio natural, o } \\
\text { socioeconômico e o cultural, sob o enfoque } \\
\text { humanista, democrático e participativo; } \\
\text { pluralismo de ideias e concepções } \\
\text { pedagógicas; }\end{array}$ \\
\hline 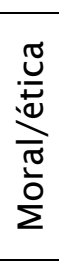 & 12 & $\begin{array}{l}\text { reconhecem que a educação tem } \\
\text { um compromisso com a formação } \\
\text { e o desenvolvimento humano } \\
\text { global, em suas dimensões } \\
\text { intelectual, física, afetiva, social, } \\
\text { ética, moral e simbólica. }\end{array}$ & 05 & $\begin{array}{l}\text { Vinculação entre ética, educação, trabalho } \\
\text { e práticas sociais na garantia de } \\
\text { continuidade dos estudos e da qualidade } \\
\text { social da educação; }\end{array}$ \\
\hline 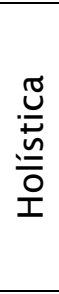 & 02 & 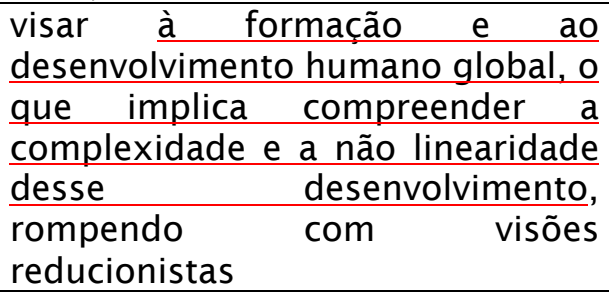 & 13 & $\begin{array}{l}\text { Desenvolver a compreensão integrada do } \\
\text { meio ambiente em suas múltiplas e } \\
\text { complexas relações para fomentar novas } \\
\text { práticas sociais e de produção e consumo; }\end{array}$ \\
\hline 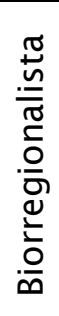 & 07 & $\begin{array}{l}\text { Ressalta-se que } \text { o conceito de } \\
\text { região faz parte das situações } \\
\text { geográficas que necessitam ser } \\
\text { desenvolvidas }\end{array}$ & 06 & $\begin{array}{l}\text { articulação na abordagem de uma } \\
\text { perspectiva crítica e transformadora dos } \\
\text { desafios ambientais a serem enfrentados } \\
\text { pelas atuais e futuras gerações, nas } \\
\text { dimensões locais, regionais, nacionais e } \\
\text { globais; }\end{array}$ \\
\hline & 32 & $\begin{array}{l}\text { espera-se que os alunos } \\
\text { compreendam os processos que } \\
\text { resultaram na desigualdade social, } \\
\text { assumindo a responsabilidade de } \\
\text { transformação da atual realidade, }\end{array}$ & 20 & $\begin{array}{l}\text { estimular a mobilização social e política e } \\
\text { o fortalecimento da consciência crítica } \\
\text { sobre a dimensão socioambiental; }\end{array}$ \\
\hline 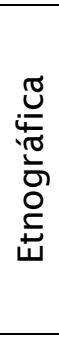 & 6 & $\begin{array}{l}\text { a educação geográfica contribui } \\
\text { para a formação do conceito de } \\
\text { identidade (...) nota-se a vivência } \\
\text { dos indivíduos e da coletividade; } \\
\text { nas relações com os lugares } \\
\text { vividos; nos costumes que } \\
\text { resgatam a nossa memória social; } \\
\text { na identidade cultural. }\end{array}$ & 3 & $\begin{array}{l}\text { valorizem o sentido de pertencimento dos } \\
\text { seres humanos à natureza, a diversidade } \\
\text { dos seres vivos, as diferentes culturas } \\
\text { locais, a tradição oral, entre outras, } \\
\text { inclusive desenvolvidas em espaços nos } \\
\text { quais os estudantes se identifiquem como } \\
\text { integrantes da natureza. }\end{array}$ \\
\hline
\end{tabular}




\begin{tabular}{|c|c|c|c|c|}
\hline 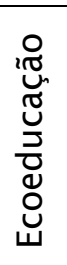 & 18 & 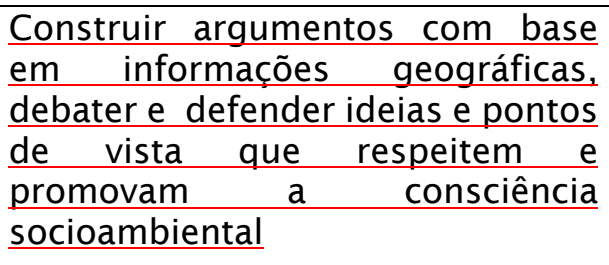 & 16 & $\begin{array}{l}\text { Os sistemas de ensino devem (...) educar } \\
\text { para a sustentabilidade socioambiental de } \\
\text { suas comunidades, integrando currículos, } \\
\text { gestão e edificações }\end{array}$ \\
\hline 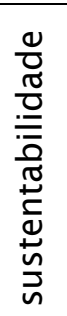 & 29 & $\begin{array}{l}\text { Agir pessoal e coletivamente com } \\
\text { respeito(...) propondo ações sobre } \\
\text { as questões socioambientais, com } \\
\text { base em princípios éticos, } \\
\text { democráticos, sustentáveis e } \\
\text { solidários. }\end{array}$ & 14 & $\begin{array}{l}\text { estímulo à constituição de instituições de } \\
\text { ensino como espaços educadores } \\
\text { sustentáveis, integrando proposta } \\
\text { curricular, gestão democrática, } \\
\begin{array}{l}\text { edificações, tornando-as referências de } \\
\text { sustentabilidade socioambiental. }\end{array}\end{array}$ \\
\hline
\end{tabular}

Fonte: Autores (2020)

A partir dos dados apresentados, a sessão que segue tem a intenção de discuti-los e lançar luzes sobre a reflexão proposta para esta pesquisa.

\section{Discussão}

Em relação à presença das correntes da EA nesses diplomas normativos, destaca-se a vinculação entre as correntes da sustentabilidade e conservacionista. Percebe-se também como as correntes humanista e crítica aparecem de modo enfático nos documentos. Ressalta-se ainda a corrente da ecoeducação no sentido da heteroformação, visto que, o sistema educativo formal, toma para si a responsabilidade de formar o ser humano em relação às questões ambientais. Chama a atenção também ausência da corrente feminista da EA nos diplomas normativos.

Evidencia-se a importância da compreensão das correntes que compõem esses diplomas normativos, haja vista que elas direcionam os caminhos pelos quais os educadores devem trilhar para o ensino da Geografia e para a promoção da EA. Explicitamente, a BNCC enfatiza a possibilidade de que, tanto a História, quanto a Geografia, possam estimular uma formação ética, pautada nos direitos humanos com respeito ao ambiente e à coletividade.

De igual maneira, atribui-se a elas a capacidade de "[...] promover explorações sociocognitivas, afetivas e lúdicas capazes de potencializar sentidos e experiências com saberes sobre a pessoa, o mundo social e a natureza" (BRASIL, 2018, p. 354). Além disso, espera-se que contribuam para a criticidade dos educandos em vista de serem protagonistas da sua história e transformadores da realidade social.

A respeito das aspirações sobre as ciências humanas, percebe-se que o caráter físico e natural da Geografia é praticamente anulado. Ao citar sobre as experiências com saberes sobre a natureza, a BNCC não enfatiza sobre qual compreensão de natureza se fala, nem quais as características e nem sob quais epistemologias se orientará.

É válido destacar que as competências gerais direcionam e perpassam toda a Educação Básica como fio condutor daquilo que deve ser desenvolvido e alcançado. Assim, são adaptadas ao contexto das ciências humanas e, essas, por sua vez, aos componentes curriculares. Esclarecese que o termo competência, etimologicamente, pode estar associado a muitas concepções e ideias. Na concepção presente na BNCC ela é definida como "[...] mobilização de conhecimentos (conceitos e procedimentos), habilidades (práticas, cognitivas e socioemocionais), atitudes e valores para resolver demandas complexas da vida cotidiana, do pleno exercício da cidadania e do mundo do trabalho" (BRASIL, 2018).

Ao apresentar essa definição de competência, a BNCC assume a ideia mercadológica da educação, visto que, está posta com uma finalidade que não é o desenvolvimento do indivíduo enquanto ser humano. Ao invés disso, "[...] direciona os interesses de aprendizagem para atender 
o mercado de trabalho, além de limitar a autonomia das escolas e, consequentemente, a atuação dos professores" (BEHREND; COUSIN; GALIAZZI, 2018, p. 76).

As 10 competências mestras presentes na BNCC contemplam dimensões da formação da pessoa humana (Figura 1).

Figura 1 - Síntese das competências gerais para a educação básica apresentadas pela BNCC

\begin{tabular}{|c|c|c|c|c|}
\hline $\begin{array}{l}\text { Valorizare utilizaros } \\
\text { conhecimentos } \\
\text { historicamente } \\
\text { construidos sobre o } \\
\text { mundo, fisico, sociale } \\
\text { cultural para intervir } \\
\text { na sociedade. }\end{array}$ & $\begin{array}{l}\text { Exercitar a curiosidade } \\
\text { intelectual, o } \\
\text { pensamento critico } \\
\text { cientifico para } \\
\text { investigar, elaborar } \\
\text { hipóteses, criar e } \\
\text { resolver problemas. }\end{array}$ & $\begin{array}{l}\text { Desenvolver o senso } \\
\text { estético para reconhecer, } \\
\text { valorizar fruir as } \\
\text { diversas manifestações } \\
\text { artisticas e culturaise } \\
\text { participar dessas } \\
\text { criaçöes. }\end{array}$ & $\begin{array}{l}\text { Utilizar as diversas } \\
\text { formas de linguagem } \\
\text { para expressar-se, } \\
\text { partilharinformaçöes, } \\
\text { experiências, ideias e } \\
\text { sentimentos que levem } \\
\text { ao entendimento } \\
\text { mútuo. }\end{array}$ & $\begin{array}{l}\text { Utilizar das tecnologias } \\
\text { digitais de forma crítica, } \\
\text { significativa, reflexiva e } \\
\text { ética para comunicar-se, } \\
\text { acessar e disseminar } \\
\text { informaçöes, produzir } \\
\text { conhecimento e resolver } \\
\text { problemas. }\end{array}$ \\
\hline conhecimento & $\begin{array}{c}\text { Pensamento } \\
\text { cientifico, crítico e } \\
\text { criativo }\end{array}$ & Senso Estético & Comunicação & Cultura Digital \\
\hline $\begin{array}{l}\text { Entender o mundo do } \\
\text { trabalho e planejaro } \\
\text { seu projeto de vida } \\
\text { pessoal, profissional e } \\
\text { social para fazer } \\
\text { escolhas em relação ao } \\
\text { futuro com liberdade, } \\
\text { autonomia e consciència } \\
\text { critica. }\end{array}$ & $\begin{array}{l}\text { Argumentar com base } \\
\text { em fatos e informaç̧̄es } \\
\text { confiáveis para formular, } \\
\text { negociar e defender } \\
\text { pontos de vista comuns } \\
\text { que promovamos } \\
\text { direitos humanos e a } \\
\text { consciência } \\
\text { socioambiental. }\end{array}$ & $\begin{array}{l}\text { Conhecer-se, apreciar- } \\
\text { se, reconhecer suas } \\
\text { emoçōes e as dos } \\
\text { outros e ter autocritica } \\
\text { para cuidar da saúde } \\
\text { fisica, emocional, lidar } \\
\text { com suas emoções e } \\
\text { com a pressão do } \\
\text { grupo. }\end{array}$ & $\begin{array}{l}\text { Exercitar a empatia, o } \\
\text { diálogo, a resolução de } \\
\text { conflitos e a cooperação } \\
\text { para fazer-se respeitar e } \\
\text { promover o respeito ao } \\
\text { outro, acolher e } \\
\text { valorizar a diversidade } \\
\text { sem preconceitos, } \\
\text { reconhecendo o coletivo }\end{array}$ & $\begin{array}{l}\text { Agir pessoalmente e } \\
\text { coletivamente com } \\
\text { autonomia, } \\
\text { responsabilidade, } \\
\text { flexibilidade, resiliência } \\
\text { e determinação para } \\
\text { tomar decisões } \\
\text { seguindo principios } \\
\text { éticos e sustentáveis. }\end{array}$ \\
\hline Autogestão & Argumentação & $\begin{array}{l}\text { Autoconhecimento } \\
\text { e autocuidado }\end{array}$ & $\begin{array}{l}\text { Empatia e } \\
\text { Cooperação }\end{array}$ & Autonomia \\
\hline
\end{tabular}

Fonte: Autores a partir da BNCC (2020)

As competências gerais apontam para aquilo que os educandos devem aprender e para a finalidade. Entre as dez gerais, são feitas apenas três menções a questões ambientais. Na competência que aborda o desenvolvimento da argumentação, espera-se que o educando ao desenvolvê-la possa tomar decisões que promovam a consciência socioambiental e 0 posicionamento ético com o cuidado do planeta. Na competência que visa o desenvolvimento da autonomia, espera-se que o educando possa agir coletiva ou individualmente amparado por princípios sustentáveis.

As três menções diretas feitas ao meio ambiente, pensando na perspectiva da EA podem ser inseridas nas correntes moral/ética, naturalista e de projetos sustentáveis. Essas correntes, respectivamente, percebem as questões ambientais como um problema ético e, portanto, depende de formação ética para solucioná-lo; a natureza como algo a ser reconectado ao ser humano e, por fim, como um recurso a ser cuidado em prol da manutenção da vida humana.

Analisando as dez competências gerais à luz das correntes propostas pela Sauvé (2005), infere-se a presença das correntes resolutiva, científica, humanista e crítica.

Reconhecendo que a BNCC visa a indicação daquilo que os educandos devem "saber" e "saber fazer", espera-se que sejam capazes de resolver problemas básicos do cotidiano e estejam abertos à possibilidade de refletir e agir em vista da resolução de problemas mais amplos, por meio do exercício da curiosidade intelectual e dos conhecimentos científicos próprios de cada ciência como descrito na competência atribuída ao pensamento científico, crítico e criativo.

Essa característica investigativa aparece ampla e claramente na corrente científica da EA. As características da corrente humanista aparecem, sobretudo, nas competências denominadas de senso estético, comunicação e empatia e cooperação. A valorização da cultura, dos saberes, das identidades e das manifestações artísticas e culturais, o respeito ao outro e aos seus direitos e 
particularidades, sem preconceitos, aparecem nessas três competências como condição sine qua non para a promoção do desenvolvimento do educando.

Essas percepções estão intimamente relacionadas à corrente da EA denominada de humanista. A Política Nacional de Educação Ambiental prevê que o enfoque humanista, holístico, democrático e participativo seja posto como um dos princípios básicos para o desenvolvimento da EA (BRASIL, 1999).

As características da corrente crítica da EA aparecem nas competências associadas à formação do pensamento crítico dos educandos. Seja para a criação e utilização das tecnologias, seja para os encaminhamentos de gestão da sua vida.

A ênfase dada à Educação nesse viés é dirigida aos educandos em suas dimensões pessoal e coletiva, de acordo e, inserido em seu tempo e espaço. No que se refere a EA ela "[...] objetiva promover ambientes educativos de mobilização desses processos de intervenção sobre a realidade e seus problemas socioambientais" (GUIMARÃES, 2004, p. 30).

No que diz respeito às correntes do pensamento geográfico, ressalta-se que prevalecem nas dez competências gerais as características das correntes crítica humanista e socioambiental.

A corrente crítica da Geografia está expressa na finalidade de aquisição do conhecimento em vista da construção de uma sociedade mais justa, democrática e inclusiva, bem como, na indicação de que o educando deve se utilizar do pensamento científico de modo crítico e criativo.

As características das correntes humanista e socioambiental da Geografia aparecem nas competências que atribuem à educação a tarefa de desenvolver nos educandos o senso de valorização das manifestações artísticas e culturais, a capacidade de, por meio da linguagem, expressar os seus sentimentos e atribuir sentido àquilo que se vive, a promoção dos direitos humanos e a capacidade de viver e dialogar com as diferenças.

A formação da consciência socioambiental e o posicionamento ético no cuidado consigo, com os outros e com o planeta aparecem nas competências, assim como os princípios de empatia, diálogo, cooperação, responsabilidade com a vida e com a promoção da sustentabilidade.

Havendo analisado as competências gerais da BNCC, optou-se por analisar também as competências das ciências humanas (Geografia e História), objetivando perceber se, e como ocorre a presença de outras correntes da Geografia e da EA a partir da definição mais específica das competências para esses componentes. A reestruturação das competências gerais para as específicas das ciências humanas busca aproximá-las das especificidades das áreas do conhecimento (Figura 2). 
Figura 2 - Síntese das competências específicas para as ciências humanas

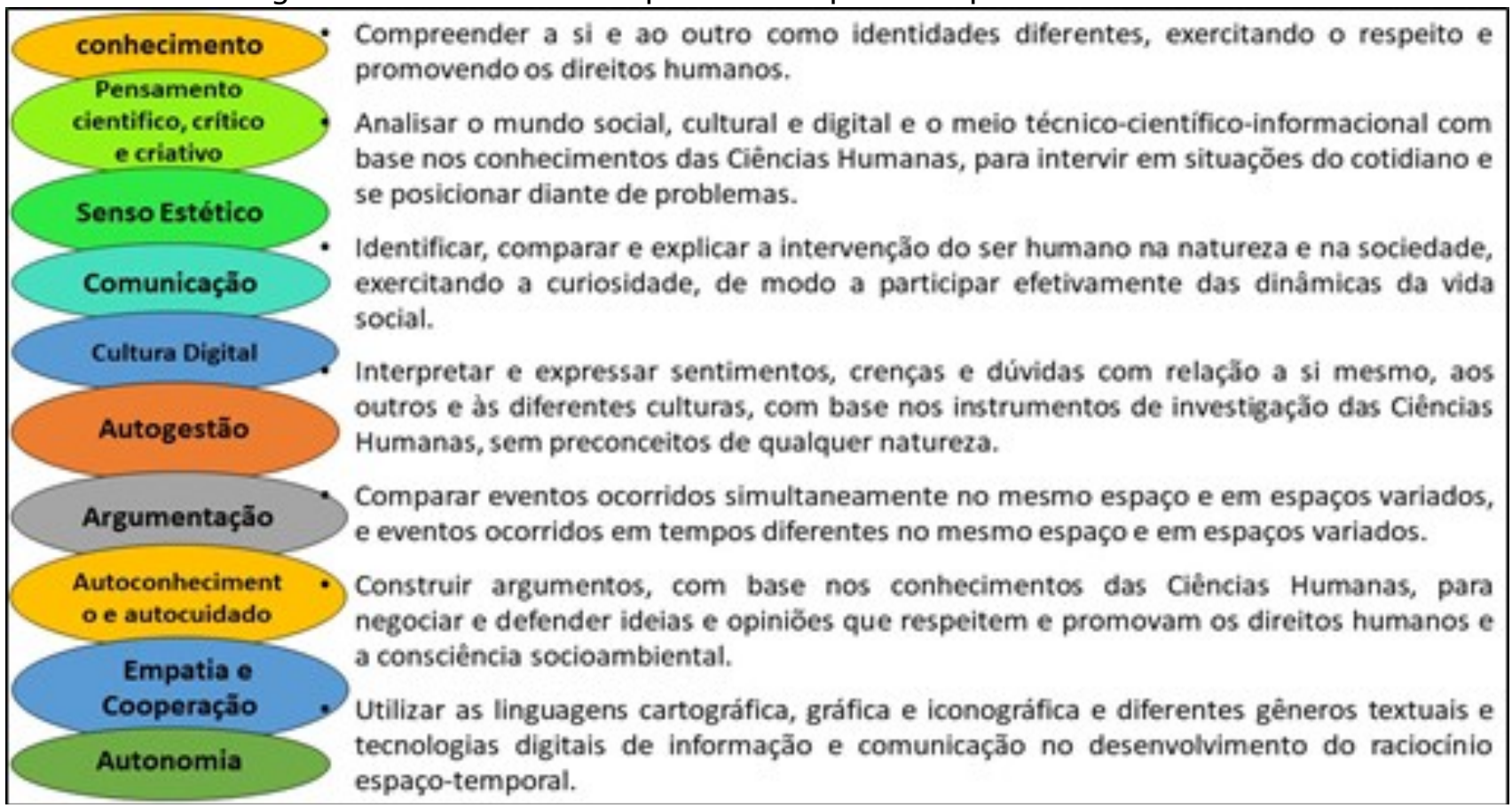

Fonte: Autores a partir da BNCC (2020)

A não definição de qual ou quais as correntes serviram de base para a construção da BNCC impossibilita aos educadores identificar e desenvolver os conteúdos a partir das mesmas bases, mesmo que seja para concordar ou discordar delas. Ainda nas competências específicas para as ciências, espera-se que o educando possa "[...] comparar eventos ocorridos simultaneamente no mesmo espaço e em espaços variados, e eventos ocorridos em tempos diferentes no mesmo espaço e em espaços variados" (BRASIL, 2018, p. 357).

A análise da construção e da transformação do espaço geográfico é feita amparada nos acontecimentos histórico-temporais. Ao trazer essas categorias como basilares na BNCC, apontase para o desenvolvimento de processos de aprendizagem que levem em consideração conjuntos de fatores que agem simultaneamente no construto da história e do espaço. "Seria impossível pensar em evolução do espaço se o tempo não tivesse existência no tempo histórico, (...) a sociedade evolui no tempo e no espaço" (SANTOS, 1979, p. 42).

A concepção de que o espaço é algo transformado constantemente pelo ser humano aparece no modo de observação da intervenção do ser humano na natureza e na sociedade. Essa competência pode favorecer a ideia de que o ser humano é livre para interferir no meio natural e para transformá-lo ao seu modo. Essa concepção tem orientado a conduta da supremacia humana sobre as outras formas de vida e sobre o planeta. Mais uma vez, reflete-se sobre a falta de apontamentos na BNCC a respeito de qual referencial está sendo utilizado para a composição das competências.

O desenvolvimento do raciocínio espaço-temporal aparece inserido nas competências associadas ao uso das linguagens, sobretudo, da linguagem cartográfica. A cartografia é um campo que ocupa lugar de prestígio na ciência geográfica e nem sempre no ensino, visto que a disciplina de Geografia, muitas vezes, está associada à simples tarefa de pintar mapas e decorar seus elementos constitutivos.

Com o advento das novas tecnologias digitais esse recurso está cada vez mais presente na vida dos seres humanos, seja motivado pela localização espacial por meio do Sistema de Posicionamento Global - mais conhecido pela sigla em inglês GPS e aplicativos de localização, seja na agricultura de precisão ou no mapeamento das cidades e afins. Contudo, a Cartografia sem critérios de leitura e interpretação do espaço perde o seu caráter interpelador e crítico da 
compreensão dos movimentos de construção, divisão e transformação do espaço.

$\mathrm{Na}$ análise realizada nas competências específicas para as ciências humanas, não foi possível identificar características de outras correntes além das destacadas nas competências gerais (Geografia crítica, humanista e socioambiental e EA moral/ética, naturalista, crítica e sustentabilidade). Contudo, observa-se a inclusão de categorias e elementos mais próprios e próximos do universo científico dos componentes História e Geografia.

Assim como realizado nas competências específicas para as ciências humanas, buscou-se analisar as características das correntes do pensamento geográfico e da EA nas competências específicas para o componente curricular Geografia na BNCC (Figura 3).

Figura 3 - Síntese das competências específicas para o componente curricular Geografia

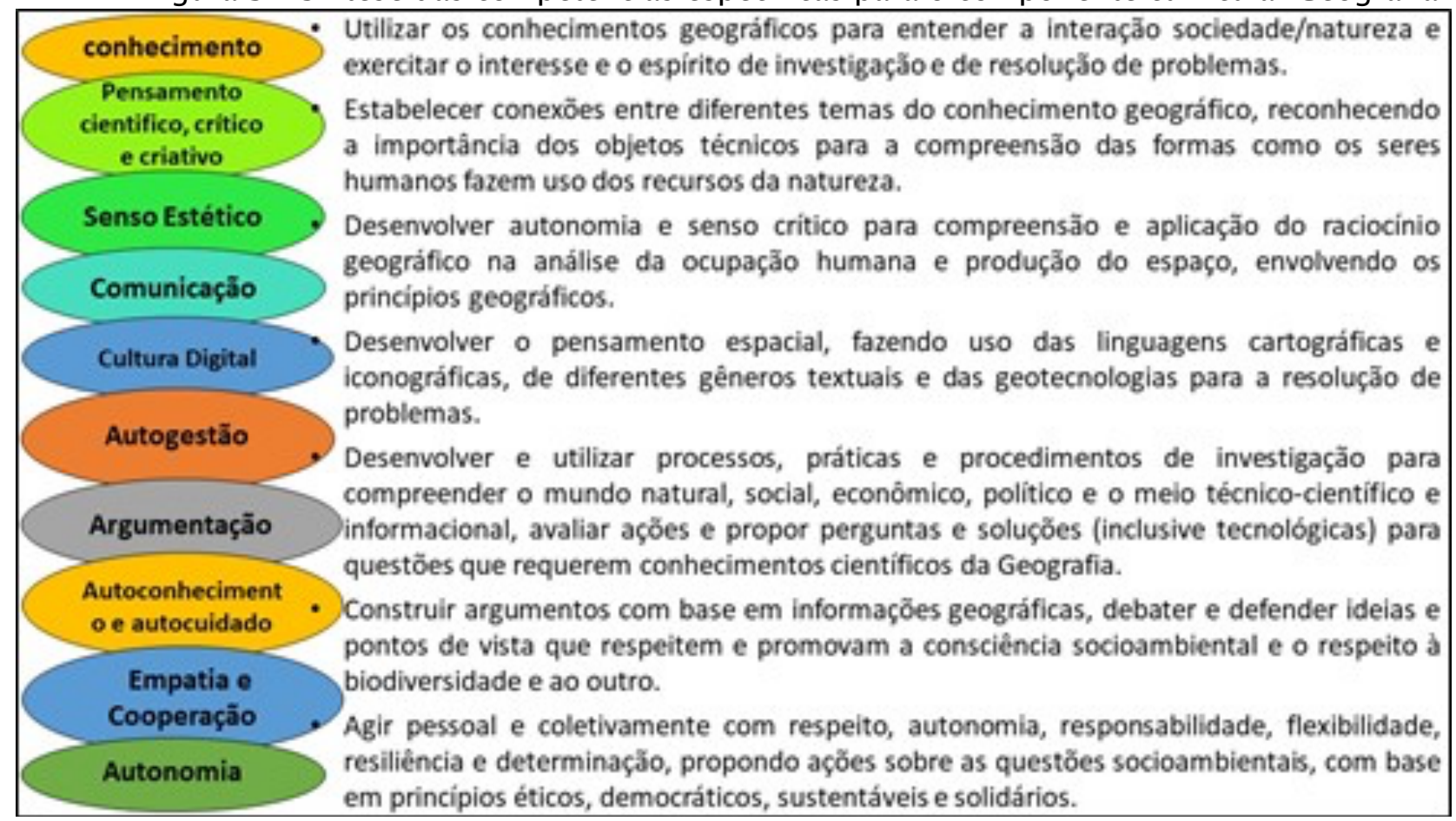

Fonte: Autores a partir da BNCC (2020)

Tendo em vista aproximar ainda mais as competências gerais ao componente curricular, das dez competências gerais, são elaborados sete grupos de competências para as ciências humanas e sete para a Geografia e para a História. Recordando que o foco dessa pesquisa é o ensino de Geografia e, por isso, foram analisadas as competências referentes a esse componente.

Trazendo a reflexão para o campo da Geografia, as competências indicam que as análises devem ser feitas sob o viés científico dessa ciência. Nesse sentido, a Cartografia aparece como meio pelo qual se conhece o espaço geográfico. Observa-se a ligação estabelecida entre a Cartografia e as geotecnologias como instrumentos para a resolução de problemas.

A BNCC estabelece relações entre as aprendizagens em Geografia, o raciocínio geográfico e o pensamento espacial. Para fazer a leitura do mundo em que vivem, com base nas aprendizagens em Geografia, os alunos precisam ser estimulados a pensar espacialmente, desenvolvendo o raciocínio geográfico" (BRASIL, 2018, p.359).

Ao propor o raciocínio geográfico com competência a ser alcançada no Ensino Fundamental, a BNCC traz como fundamentação os princípios da Geografia, a saber: analogia, conexão, diferenciação, distribuição, extensão, localização e ordem.

A perspectiva do pensamento espacial não é exclusiva da Geografia, "o pensamento espacial está associado ao desenvolvimento intelectual que integra conhecimentos não somente 
da Geografia, mas também de outras áreas (como Matemática, Ciência, Arte e Literatura)"(BRASIL, 2018, p. 359).

A base do pensamento espacial defende que existem muitas formas de pensar e de expressar-se. A BNCC toma o pensamento espacial para a Geografia, levando em consideração que pode ser entendido como uma forma de pensar amparada em uma coleção de habilidades cognitivas que podem ser usadas para transformar e ou combinar outras formas de processar esse conhecimento. "A tarefa de fazer a educação geográfica supõe desenvolver o pensamento espacial e trabalhar com os conceitos de modo que eles sejam significativos para desencadear as aprendizagens" (CALLAI, 2013, p. 18).

É válido destacar que se as competências específicas do componente Geografia trazem novos elementos, na mesma medida, outros são deixados pelo caminho. As questões que envolvem a valorização da cultura, o desenvolvimento do cuidado de si, do outro e do planeta, não aparecem nesse grupo de competências.

A BNCC estabelece como diretriz a formação integral da pessoa humana. 0 termo integral utilizado não está se referindo à educação em tempo integral, ou à escola de tempo integral. Ele se refere "[...] à construção intencional de processos educativos que promovam aprendizagens sintonizadas com as necessidades, as possibilidades e os interesses dos estudantes e, também, com os desafios da sociedade contemporânea" (BRASIL, 2018, p. 14).

Havendo realizado a análise das competências gerais e específicas das ciências humanas e da Geografia, em vista de identificar as correntes do pensamento geográfico e da EA que aparecem explícita e implicitamente, optou-se por realizar na Resolução $n^{\circ} 2$, de 15 de junho de 2012, o mesmo processo metodológico aplicado na análise da BNCC.

No que diz respeito à presença das correntes da EA, suas características aparecem em maior número e de forma mais enfática que na BNCC, como era de se esperar por se tratar de um documento específico para a EA.

A respeito da $E A$, afirma-se que ela não é um apêndice da educação e menos ainda outra educação. Ao afirmar que a EA possui a prática social como atividade diretora, reforça-se a ideia de que por trás de cada ação da educação há uma intencionalidade. Esse é um ponto de fortaleza da Educação, mas revela a necessidade de visões críticas sobre quais direções a educação tem sido conduzida, melhor dizendo, a quais interesses ela tem servido. Nessa definição revela-se a corrente moral/ética da EA, ao entender "[...] existem caminhos capazes de apontar perspectivas para pensarmos a dimensão ética da educação ambiental" (GRÜN, 2012, p. 78).

A corrente crítica da EA aparece de modo enfático ao acentuar que ela "não é atividade neutra, pois envolve valores, interesses, visões de mundo e, desse modo, deve assumir na prática educativa, de forma articulada e interdependente, as suas dimensões política e pedagógica" (BRASIL, 2012).

Essa visão traz a cerne do pensamento Freiriano ao indicar que nenhuma educação é neutra. "A educação é sempre um ato político" (FREIRE, 2014, p.15). Assim, qualquer postura que ela venha a assumir fará em nome de um posicionamento político e ideológico.

As Diretrizes reconhecem que a educação no Brasil vem ocorrendo de forma fragmentada e despolitizada, por isso apregoa que a EA rompa com esse modelo e adote uma "[...] abordagem que considere a interface entre a natureza, a sociocultura, a produção, o trabalho, o consumo, superando a visão despolitizada, acrítica, ingênua e naturalista" (BRASIL, 2012).

Corroborando com essa percepção, Loureiro (2004, p. 76) afirma que a EA no Brasil se desenvolveu "[...] favorecendo a proliferação dos discursos ingênuos e naturalistas e a prática focada na sensibilização do "humano" perante o "meio natural", ambos desvinculados dos debates sobre modelos societários como um todo".

$\mathrm{Na}$ definição de Carvalho $(2012$, p. 35) essa concepção "[...] naturalizada tende a ver a natureza como o mundo da ordem biológica, essencialmente boa, pacificada, equilibrada, estável em suas interações ecossistêmicas". O mundo humano e cultural é percebido como oposto ao mundo naturalizado e a presença do ser humano nesse ambiente é considerada como algo nefasto. 
Embora nesse trecho que diz respeito ao objeto das Diretrizes prevaleçam as características da corrente crítica, caracteriza-se também na corrente sistêmica, visto que essa corrente possibilita "[...] identificar os diferentes componentes de um sistema ambiental e salientar as relações entre seus componentes, como as relações entre os elementos biofísicos e os sociais" (SAUVÉ, 2005', p. 22).

Amparada na Lei $n^{\circ} 9.795$, de 1999, as Diretrizes estabelecem os princípios da EA fundados em práticas que estejam comprometidas com a "[...] construção de sociedades justas e sustentáveis, fundadas nos valores da liberdade, igualdade, solidariedade, democracia, justiça social, responsabilidade, sustentabilidade e educação como direito de todos" (BRASIL, 2012).

Ao apregoar que a promoção da EA deve amparar-se nessas causas, compreende-se que o educador deve orientar suas práticas por meio das correntes crítica, sistêmica e de sustentabilidade. É importante destacar que a compreensão de sustentabilidade apresentada está para além da preservação de recursos, contempla a justiça, a liberdade, a igualdade e a solidariedade.

As DCNEA, diferentemente da BNCC, indicam a categoria e enfoque sob os quais a EA deve orientar-se, no caso, levando a totalidade como categoria de análise e produção do conhecimento sobre o meio ambiente, sob o enfoque humanista, democrático e participativo. Assim, "[...] referindo-se à totalidade de cada ser, de cada realidade, e à rede de relações que une os seres entre si em conjuntos onde eles adquirem sentido" (SAUVÉ, 2005, p.27), traz as características de modo enfático das correntes holística, humanista e científica.

Ao assumir esse caráter, a EA evoca para si a produção do conhecimento e desenvolvimento de ações sob a perspectiva transversal e interdisciplinar. Reforçando essa ideia as Diretrizes afirmam que a EA deve ser inserida nos currículos "[...] pela transversalidade, como conteúdo dos componentes já constantes do currículo; pela combinação de transversalidade e de tratamento nos componentes curriculares" (BRASIL, 2012).

A busca pela transformação da Educação e dos modelos de vida adotados pelos seres humanos é retomada constante no documento. Além de reforçar a característica crítica da EA, direciona-se que ela seja também "[...] transformadora dos desafios ambientais a serem enfrentados pelas atuais e futuras gerações, nas dimensões locais, regionais, nacionais e globais" (BRASIL, 2012).

A EA pautada nesses valores busca ampliar a visão de mundo dos educandos, sem desprezar os aspectos locais e sem restringir o educando ao seu próprio mundo. A concepção de EA transformadora está "[...] estritamente na condição de uma nuance inserida no campo libertário da educação ambiental, no qual se inscrevem abordagens similares (emancipatória, crítica, popular, eco pedagógica, entre outras)" (LOUREIRO, 2004, p. 65).

Nessa circunstância a EA toma características da corrente práxica que "consiste em transformar a realidade por meio da integração entre a "reflexão e ação alimentando-se mutuamente" (SAUVÉ, 2005, p. 29). O caráter transformador da Educação apresenta-se como uma característica constituinte do seu papel na vida do educando.

No que diz respeito aos objetivos da EA, segundo as Diretrizes, levando em consideração as fases, etapas, modalidades e nível de ensino, o seu desenvolvimento deve almejar 0 desenvolvimento da compreensão integrada do meio ambiente em suas múltiplas e complexas relações para fomentar novas práticas sociais e de produção e consumo.

A garantia e democratização do acesso às informações sobre a área socioambiental, bem como o estímulo à mobilização individual, coletiva e responsável, levando em consideração os aspectos sociais e políticos da temática socioambiental, aparece como objetivos da EA em vista da defesa e da preservação do equilíbrio do meio ambiente.

Ressalta-se que há um avanço na compreensão de conservação e defesa do meio ambiente ecologicamente equilibrado, pois aqui ele não é visto isolado dos demais aspectos que compõem a vida no planeta, nessa compreensão é inserido no contexto da ética, afirmando que mantê-lo é um exercício de cidadania.

O estímulo à cooperação entre as regiões do país, buscando auxílio da ciência e tecnologia, 
visando a sustentabilidade ambiental, aparecem como caminho para a construção de uma sociedade ambientalmente sustentável. Nesse aspecto, a regionalidade é ressaltada como fator de identidade e agrupamento.

Embora cada região mantenha as suas características próprias, ela necessita somar esforços com outras regiões. As características das correntes biorregionalista e de sustentabilidade marcam esse objetivo da EA.

A corrente etnográfica cuja principal característica é a "[...] ênfase cultural da relação com o meio ambiente" (SAUVÉ, 2005, p. 34), aparece no documento resguardando o objetivo da EA de "fortalecer a cidadania, a autodeterminação dos povos e a solidariedade (...) valendo-se de estratégias democráticas e da interação entre as culturas, como fundamentos para o futuro da humanidade"(BRASIL, 2012).

A promoção do cuidado com a comunidade de vida e a integridade dos sistemas também aparecem como objetivos a serem alcançados pela EA, particularmente no ensino formal, mas não só nele.

Desta forma, cabe às instituições de ensino do país a organização curricular de modo a contemplar e alcançar os objetivos que põem a EA. Compreendendo que, na Educação Básica, ela se dá de modo interdisciplinar e transversal, buscando estabelecer vínculos entre a EA e a Geografia, realizou-se também o mapeamento das características das correntes do pensamento geográfico presentes nas Diretrizes.

Destaca-se que as Diretrizes não se constituem um documento normativo para o ensino de Geografia, o exercício realizado nesta pesquisa traduz-se em uma reflexão teórica em vista de auxiliar os educadores a perceberem os vínculos entre as correntes dessas duas áreas e apontar possibilidades de promoção da interdisciplinaridade e da transversalidade.

As correntes do pensamento geográfico identificadas nas DCNEA através de suas características foram a regional, humanista, socioambiental e a crítica. A corrente regional aparece por meio da valorização da categoria geográfica de Região como um modo de perceber e valorizar as especificidades de cada lugar, pensando na resolução dos problemas em diferentes escalas. A corrente humanista aparece explicitamente como o enfoque escolhido para direcionar as reflexões sobre a EA. Ressalta-se que para a identificação da corrente humanista, para além da palavra que aparece no texto, foi levado em consideração o contexto no qual a palavra está inserida.

Reconhecendo que as características da corrente humanista se aproximam daquilo que é proposto pela Geografia socioambiental, apresenta-se a compreensão de que essa segunda corrente tem suas características contempladas pelas Diretrizes da EA.

A valorização do pensamento científico como meio para o aprofundamento das reflexões sobre os campos socioeconômicos, políticos e históricos amparados na dimensão socioambiental do planeta sinaliza a presença da corrente socioambiental, levando em consideração que o meio ambiente é constituído pelas dimensões econômicas, políticas, sociais e naturais.

Outro fator importante é a presença da corrente crítica da Geografia. O reconhecimento da necessidade de contraposição ao sistema hegemônico de dominação e exploração da realidade atual reivindica para a EA e para a Geografia a promoção de educandos capazes de transformar a realidade na qual estão inseridos, ampliar sua visão para o macro e compreender as interrelações entre essas esferas do espaço.

\section{Conclusão}

A partir da análise da BNCC e das DCNEA percebe-se que ambos trazem diferentes possibilidades interpretativas sobre o modo de ensino da Geografia e de promoção da EA. Considerando-se que o fato de a BNCC não deixar claro quais as bases geográficas sob as quais ela está amparando-se, pode gerar dificuldades conceituais e práticas sobre temas que, na Geografia, não são unânimes no modo de compreensão, a exemplo do regionalismo. Outro ponto que merece destaque em relação a BNCC é que o documento não apresenta um referencial teórico no campo geográfico, a existência desses dados diminuiria a 
possibilidade de confusão conceitual sobre o entendimento do direcionamento dos temas por ela sugeridos.

Realizando uma análise comparativa entre os documentos analisados é possível afirmar que a BNCC, no campo da EA retrocedeu em relação às DCNEA, pois a BNCC faz apenas três menções diretas ao meio ambiente ao longo do seu texto. Compreende-se que em meio a tantas possibilidades por ela apresentadas, a inexistência das temáticas ambientais sugere aos educadores que esse campo não é importante e que outros devem receber mais atenção que as temáticas ambientais. No campo geográfico em particular, apresenta-se um vácuo no que diz respeito às temáticas físicas desta ciência, reforçando a velha dicotomia entre a importância da dita Geografia humana em detrimento da Geografia física.

Em relação as correntes apresentadas em ambos os documentos, percebe-se que é possível aos educadores promoverem o ensino da Geografia e a vivência da EA a partir de referenciais que dialoguem e que favoreçam o planejamento e a execução de uma educação contínua nesses campos, rompendo com o caráter pontual e descontínuo sob os quais correm o risco de pautar-se o desenvolvimento da EA.

Considera-se que para a promoção de uma educação significativa e promotora de transformação humana e social, faz-se necessário sustentar as práticas sob bases sólidas e edificantes. A BNCC silenciar as questões ambientais do seu texto, compromete o desenvolvimento da EA nas escolas e lança luzes para a promoção de uma educação geográfica fragmentada e descomprometida com a realidade ambiental em escala local e global. Percebe-se que se faz necessário o aprofundamento teórico e prático nesses campos em vista de fortalecer o diálogo entre eles. Acentua-se ainda que esta pesquisa serve como base interpretativa para que outras pesquisas possam desenvolver a temática, sobretudo, construindo encaminhamentos metodológicos que efetivamente estabeleçam a conexão entre os autores desses correntes, em vista de auxiliar os educadores no cotidiano escolar.

\section{Referências}

ALENCASTRO, Mario Sergio Cunha; SOUZA-LIMA, José Edmilson De. Educação Ambiental: Breves Considerações Epistemológicas. Revista Meio Ambiente e Sustentabilidade, Curitiba, PR, v. 8, n. 4, p. 20-50, 2015.

\section{ANDRADE, Manuel Correia De. Geografia, ciência da sociedade: uma introdução à análise do pensamento geográfico. São Paulo, SP: Atlas, 1987.}

BEHREND, Danielle Monteiro; COUSIN, Cláudia Da Silva; GALIAZZI, Maria Do Carmo. Base Nacional Comum Curricular: O Que Se Mostra De Referência À Educação Ambiental? Ambiente \& Educação, Rio Grande do Sul, RS, v. 23, n. 2, p. 74-89, 2018.

BRASIL. LEI No 9.795, DE 27 DE ABRIL DE 1999: Dispõe sobre a educação ambiental, institui a Política Nacional de Educação Ambiental e dá outras providências. BRASIL. Lei $n^{\circ}$ 9.795, de 27 de abril de 1999. Dispõe sobre a educação ambiental, institui a política nacional de educação ambiental e dá outras providências. Diário Oficial da União, Brasília, 28 abr. 1999. Diário Oficial, Brasília, DF, 1999. p. 2. Disponível em:

<http://portal.mec.gov.br/secad/arquivos/pdf/educacaoambiental/lei9795.pdf>Acesso em 30 mai 2021

BRASIL. Base Nacional Comum CurricularMinistério da Educação, Brasília, DF, 2018. p. 600. Disponível em:

<http://revistas.pucsp.br/index.php/curriculum/article/view/21666/15916> Acesso em 30 mai 2021 
BRASIL, Ministério da Educação Conselho Nacional de Educação Conselho Pleno. Resolução № 2, De 15 De Junho De 2012. Estabelece as Diretrizes Curriculares Nacionais para a Educação Ambiental.Diário Oficial da União, Brasília, DF, 2012. p. 70.

CARVALHO, Isabel Cristina de Moura. Educação Ambiental: a formação do sujeito ecológico. 6. ed. São Paulo, SP: Cortez, 2012.

CHRISTOFOLETTI, Antônio. Perspectivas da Geografia. 2. ed. São Paulo, SP: Defel, 1985.

CLAVAL, Paul. A revolução pós-funcionalista e as concepções atuais da geografia. In: MENDONÇA, Francisco; KOZEL, Salete (Eds.). Elementos de Epistemologia da Geografia Contemporânea. Curitiba, PR: UFPR, 2009. p. 11-43.

CORREA, Roberto Lobato. Região organização espacial. São Paulo, SP: Ática, 1986.

FREIRE, Paulo. Educação e Mudança. 36. ed. São Paulo, SP: Paz \& Terra, 2014.

GRÜN, Mauro. Ética e Educação Ambiental: a conexão necessária. Campinas, SP, 2012.

GUIMARÃES, Mauro. Educação Ambinetal Crítica. In: Identidades da Educação Ambiental Brasileira. Brasília, DF: Ministério do Meio Ambiente, 2004. p. 25-34.

LIMA, Gustavo Ferreira da Costa. Educação ambiental crítica: Do socioambientalismo às sociedades sustentáveis. Educacao e Pesquisa, São Paulo, SP, v. 35, n. 1, p. 145-163, 2009.

LIMBERGER, Leila. Abordagem sistêmica e complexidade na geografia. Geografia, Rio Claro, SP, v. 15, n. 2, p. 95-109, 2006.

LOUREIRO, Carlos Frederico Bernardo. Educação ambiental tranformadora. In: Identidades da Educação Ambiental Brasileira. Brasília, DF: Ministério do Meio Ambiente, 2004. p. 65-84.

MENDONÇA, Francisco. Geografia Socioambiental. In: MENDONÇA, Francisco; KOZEL, Salete (Eds.). Elementos de Epistemologia da Geografia Contemporânea. Curitiba, PR. p. 121-144.

MORAES, Antônio Carlos Robert. Geografia: pequena história crítica. 21 ed. ed. São Paulo, SP: Anablume, 2007.

SAHEB, Daniele. A Educação Ambiental na formação em Pedagogia. 2008. Dissertação (Mestrado) Programa de Pós-Graduação de Educação- Universidade Federal do Paraná, Curitiba, PR, 2008. Disponível em:

<http://www.ppge.ufpr.br/teses/teses/M08_saheb.pdf>. Acesso em 30 mai 2021

SAHEB, Daniele. Os saberes socioambientais e a formação do educador ambiental sob o foco da complexidade. 2013. Tese (Doutorado) Programa de Pós-Graduação de Educação- Universidade Federal do Paraná, Curitiba, PR, 2013. Disponível em: < https://acervodigital.ufpr.br/handle/1884/36381 > Acesso em 30 mai 2021

SANTOS, Milton. Espaço e Sociedade. Petrópolis, RJ: Vozes, 1979. 
SAUVÉ, Lucie. Uma cortografia das correntes em educação ambiental. In: SATO, Michèle; CARVALHO, Isabel Cristina Moura (Eds.). Educação Ambiental: Pesquisa e Desafios. Porto Alegre, RS: Artmed, 2005. p. 17-44.

SOUZA, Carolina Gusmão et al. As principais correntes do pensamento geográfico: uma breve discussão da categoria de análise de lugar. Enciclopédia Biosfera. Centro Cientifico Conhecer, Santa Maria, RS, v. 07, 2009. Disponível em:

<https://docplayer.com.br/5393785-As-principais-correntes-do-pensamento-geograficouma-breve-discussao-da-categoria-de-analise-de-lugar.html>

TUAN, Yu Fu. Espaço e Lugar: a perspectiva da experiência. São Paulo, SP: DIFEL, 1983.

VESENTINI, José William. Geografia Crítica e Ensino. In: OLIVEIRA, Ariovaldo Umbelino De (Ed.). Para onde vai o ensino de Geografia? São Paulo, SP: Contexto, 1994. p. 30-38. 


\section{Diego Andrade de Jesus Lelis}

Possui graduação em Geografia (Licenciatura) pelo Centro Universitário Claretiano-CEUCLAR (2014) e em Filosofia pelo Instituto Santo Tomás de Aquino-ISTA. (2016). Possui Especialização na área de Tutoria em Educação a Distância e EJA, em Educação Especial e Ensino Religioso, e em Geografia, História e Sustentabilidade pela Faculdade Futura. É Mestre em Educação pela Pontifícia Universidade Católica do Paraná-PUCPR, membro Grupo de Pesquisa Criatividade e Inovação Docente no Ensino Superior (Cides) na mesma instituição e Bacharelando em Teologia pelo Centro Universitário Claretiano-CEUCLAR. É estudante licenciado para o treinamento de usuários do software de análise de dados qualitativos ATLAS.ti. Está doutorando em Educação no Programa de Pós Graduação em Educação- PPGE da PUCPR.E-mail: diego.lelis@pucpr.edu.br. ORCID: https://orcid.org/0000-0002-44192978.

\section{Daniele Saheb Pedroso}

Professora Titular do Curso de Pedagogia e do Programa de Pós-Graduação em Educação da Pontifícia Universidade Católica do Paraná (PUCPR). Vice-líder do Grupo de pesquisa: Aprendizagem e Conhecimento na Prática Docente (PUCPR) e Coordenadora do Grupo de Estudos e Pesquisa em Educação Ambiental e Complexidade (GEPEACOM). DOUTORA em Educação (Programa de Pós-Graduação em Educação) pela Universidade Federal do Paraná (2013). Possui GRADUAÇÃO em Pedagogia, ESPECIALIZAÇÃO em Educação, Meio Ambiente e Desenvolvimento (2006), MESTRADO em Educação (Programa de Pós-Graduação em Educação) pela Universidade Federal do Paraná (2008). Coordenadora do Núcleo na PUCPR da Rede Internacional de Escolas Criativas - RIEC. Coordenadora do Projeto na PUCPR Pacto Mundial da Juventude pelo Clima - coordenado por Alfredo Pena-Vega do Centro Edgar Morin, EHSS / CNRS, Paris, França. Possui experiência em pesquisa, docência e gestão na Educação Básica (Educação Infantil e Anos Iniciais) e no Ensino Superior. Pesquisas com ênfase em Educação Ambiental, Complexidade e Transdisciplinaridade, atuando principalmente nos seguintes temas: Formação e Prática Docente em Educação Ambiental na visão da Complexidade e da Transdisciplinaridade. E-mail: daniele.saheb@pucpr.br. ORCID: https://orcid.org/0000-0003-1317-6622. 